\title{
Spatial multicriteria model to analyze residential segregation in the colonias of El Paso, Texas
}

\author{
Adrián Botello Mares ${ }^{1}$ \\ http://orcid.org/0000-0003-4515-0996 \\ Erick Sánchez Flores ${ }^{2}$ \\ http://orcid.org/0000-0001-7963-1128 \\ Primera versión recibida en: 17 julio, 2020 \\ Última versión recibida en: 01 septiembre, 2020
}

\begin{abstract}
\end{abstract}

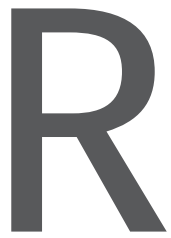

esidential segregation, as an expression of the socio-economic differences of the population in the territory, is a phenomenon that has been studied from different perspectives, since segregation spaces manifest themselves in different ways, depending on the socio-cultural context in which they occur. However, having tools that allow its systematic identification and characterization, facilitates its approach as public policy spaces, for the improvement of the population's living conditions. In this paper, we present the conceptual and methodological bases to approach the phenomenon of residential segregation from a set of spatial variables that explain objectively its

1 Licenciado en Sociología por la Universidad Autónoma de Ciudad Juárez (UACJ) y maestro en Geografía por la UNAM; ganó el Premio Nacional a la Mejor Tesis de Posgrado en la categoría de Geografía Social por parte de la Sociedad Mexicana de Geografía y Estadística en el 2015. Hoy en día es docente y asistente de investigación en El Colegio de Chihuahua y estudiante del Doctorado en Estudios Urbanos en la UACJ.

2 Geógrafo especialista en análisis espacial y sistemas de percepción remota; es doctor en Geografía por la Universidad de Arizona. Ha publicado su trabajo en dos libros y en más de 20 artículos en revistas nacionales e internacionales, además de colaborar como revisor de revistas nacionales y de editoriales internacionales como Elsevier, Springer y Academic Journals. Ha sido miembro de la Sociedad Latinoamericana de Percepción Remota y Sistemas de Información Espacial (SELPER), de la American Society of Photogrammetry and Remote Sensing (ASPRS) y de la Association of American Geographers (AAG). Además, es evaluador acreditado del Conacyt y del Consejo para la Acreditación de Programas Educativos en Humanidades. Desde 2008 es miembro del Sistema Nacional de Investigadores. En 1997 recibió la presea "Ignacio Altamirano" a la excelencia estudiantil por parte de la UAEM; en 2008 recibió la medalla "Maestros Fundadores" al mérito docente por la UAC); y en 2014 la presea "Isidro Fabela" por el municipio de Atlacomulco, Estado de México. Desde 1997 es profesor investigador en la Universidad Autónoma de Ciudad Juárez.

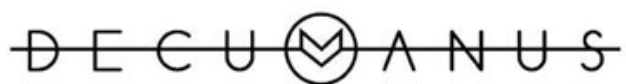

REVISTA INTERDISCIPLINARIA SOBRE ESTUDIOS URBANOS 
distribution, using a multicriteria evaluation model. Particularly, we analyzed the case of study of the border city of El Paso, Texas, and its colonias, considering basic services, accessibility and population characteristics variables, derived from 2015 census data. Results show the highest concentration of residential segregation in the so-called colonias, because of the income conditions, below the poverty line, the distance from the central business district of the city, the lack of public transportation routes, and the deficiencies in residential services. The spatially expressed segregation variables allow for a better understanding of the phenomenon in measurable terms.

Keywords: Colonias, El Paso, residential segregation, multicriteria model.

\section{Modelo espacial multicriterio de la segregación residencial en las colonias de El Paso, Texas.}

\section{Resumen}

La segregación residencial, como expresión de las diferencias socioeconómicas de la población en el territorio, es un fenómeno que se ha estudiado desde diferentes perspectivas, ya que los espacios de segregación se manifiestan de formas distintas, dependiendo del contexto sociocultural en el que ocurren. Sin embargo, contar con herramientas que permitan su identificación y caracterización sistemática, facilita su abordaje como espacios de política pública para la mejora de las condiciones de vida de la población. En este artículo presentamos las bases conceptuales y metodológicas para abordar el fenómeno de la segregación residencial a partir de un conjunto de variables espaciales que explican objetivamente su distribución, mediante un modelo de evaluación multicriterio. Particularmente, abordamos el caso de estudio de la ciudad fronteriza de El Paso, Texas, y sus colonias, utilizando conjuntos de variables de relacionadas con la disponibilidad de servicios básicos, la accesibilidad, y las características sociodemográficas de la población, derivadas de datos censales del 2015. Los resultados del modelo muestran la concentración de los niveles más altos de segregación residencial en las llamadas colonias, debido a las condiciones de ingresos por debajo de la línea de pobreza, la distancia desde el distrito central de negocios de la ciudad, la falta de rutas de transporte público y las deficiencias en servicios residenciales. Las variables de segregación expresadas espacialmente en el modelo facilitan la comprensión del fenómeno en términos medibles.

Palabras clave: Colonias, El Paso, segregación residencial, modelo multicriterio.

\section{Introduction}

The historical process in the configuration of the United States of America (USA) / Mexico borderland cities has developed based on common cultural heritages, as

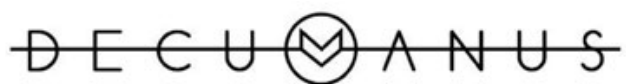

REVISTA INTERDISCIPLINARIA SOBRE ESTUDIOS URBANOS 
well as strong social and economic ties. Nonetheless, it also has notorious differences on both sides of the border, explained by profound socioeconomic and political asymmetries. From the urban perspective, one of the problems that reflects such disparities is the segregation; specifically, in the U.S. border cities segregation manifests with notoriety in peri-urban settlements called colonias. In the state of Texas, these settlements are located mainly along the Rio Grande, and in areas contiguous to some cities Mexico, in the states of New Mexico and Arizona.

According to Castells (1978), segregation is the tendency to organize space in areas with strong social disparities among them, which should be understood not only in terms of difference, but also in terms of hierarchy. Therefore, it is evident that if cities are larger and there is more growth, it is easier to identify segregation conditions. Specifically, for Sabatini (2002), residential segregation is the geographical agglomeration of families of the same social condition, understood as a complex interconnected spatial phenomenon that is defined based on population characteristics, which may be of a socioeconomic type, cultural, ethnic, racial, occupational or other. Rodríguez and Arriagada (2004) stated that residential segregation refers to forms of unequal distribution of population groups in the territory, which are manifested in different ways, such as: the physical proximity between the residential spaces of the different social groups, the social homogeneity of the different territorial subdivisions and the concentration of social groups in specific areas of a city.

Sabatini (2004) affirms that segregation studies connect the economic, cultural and political dimensions with the spatial dimensions of social reality. Therefore, in addition of being a relevant, objective and measurable condition, segregation also implies a subjective dimension, which considers the perception of the inhabitants of the city regarding to the segregated urban spaces. In fact, this author argues that residential segregation has three main dimensions, he had already distinguished between objective and subjective: 1 . The tendency of certain social groups to concentrate in some areas of the city; 2 . The conformation of areas with a high degree of social homogeneity; and 3. The subjective perception that people have of objective segregation (the first two dimensions). For this work, we focused on the first two dimensions. This conceptual framework of residential segregation, therefore, allows considering the measurable objective dimensions of the phenomenon itself, however, the findings achieved here may be an input for subsequent studies that integrate the subjective perspective.

Derived from this conceptual frame, the objective for this work is, to elaborate a quantitative spatial model for the city of El Paso, Texas, where the specific situation of the colonias, in terms of residential segregation, is highlighted. The contribution of this research focuses, then, on the assessment of residential segregation, based on the distribution of socio demographic variables and spatial indicators integrated into a multicriteria analysis model, constructed with geographic information tools. It is expected that this model might provide an opportunity to contemplate the phenomenon from an objective perspective, based on the explicit distribution of the factors affecting residential segregation. The multicri-

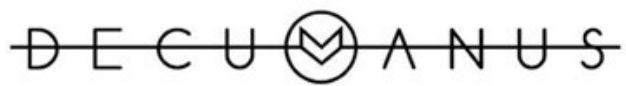

REVISTA INTERDISCIPLINARIA SOBRE ESTUDIOS URBANOS
Núm. 5. Vol. 5. Octubre 2019-Octubre 2020. Instituto de Arquitectura, Diseño y Arte.

Universidad Autónoma de Ciudad Juárez. ISSN: 2448-900X 
teria analysis method was considered appropriate for this assessment due to its feasibility for the organization of variables and their spatial outcomes in the form of geo-demographic grouping and spatial dissimilarity as the analytical basis for the multicriteria analysis itself.

\section{Study Area}

On the Mexico-US border, residential segregation has been historically associated with precarious spaces with disadvantages in terms of development called colonias. Ward (1999) defines the colonias as those human settlements where low-income populations live, mainly of Mexican origin, who had access to housing through the purchase of land at low cost, generally without basic services such as water, sewer system, natural gas, and paving. This type of settlement consists of self-built and mobile homes that adapts to the possibilities and needs of their inhabitants.

Ward (1999) focuses the problem on the development of unregulated land, which developers took advantage for what he defines as the "mortgage of the poor". In terms of its urban geography, Ward (1999) defines peri-urban areas as a "suburbanization of poverty", rather than the urbanization of poverty as it happens in Latin America. In the US, the colonias started as self-built settlements in the suburbs or semi-urban and rural areas, but in Latin America self-built settlements are relatively consolidated in urban areas, with a relative high provision of services, paved streets and homes well settled. The colonias in the US arose since the 1950s due to a lack of adequate regulation in the processes of subdivision and urbanization of the land, given the demand for affordable housing for the Mexican immigrants of the Bracero Program. Private companies used this mechanism to sell land at very low costs, but without some of the basic services, in the peripheries of the cities (Olmedo, 2014; Rivera, 2014; Ward, 1999; Mauleón and Ting, 2017).

The colonias became officially recognized and defined in 1990, under the National Affordable Housing Act Cranston-González, with following characteristics (Rivera, 2014):

1. Colonias are located within one of the four Border States with Mexico (California, Arizona, New Mexico or Texas).

2. They are located within a margin of 150 miles from the border and not within a metropolitan area with more than one million people.

3. There is an according designation by the corresponding state and/or county.

4. They lack potable water, adequate wastewater systems and / or decent, safe and sanitary housing.

5. They were recognized as colonias before this law.

According to these characteristics and with the definition of residential segregation, it might be considered that the colonias are in a situation of residential segregation.

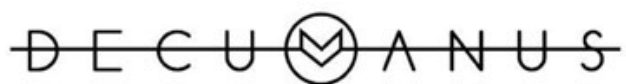

REVISTA INTERDISCIPLINARIA SOBRE ESTUDIOS URBANOS 
In El Paso, TX., the colonias are located particularly on the urban fringe: to the north in the Upper Valley along the Strehan Road; to the south in the Lower Valley; and to the east, north and south of the national highway in Krag and Montana Vista (Ward, 1999). According to Mauleón and Ting (2017), in El Paso County there are 80000 people living in more than 200 known colonias. Figure 1 illustrates the distribution of the colonias, showing a concentration in the southeast area of the city, very close to the border with Mexico in Ciudad Juárez, as well as in the extreme northeast and northwest areas of the urban limits.

Figure 1. Colonias in El Paso, Texas.

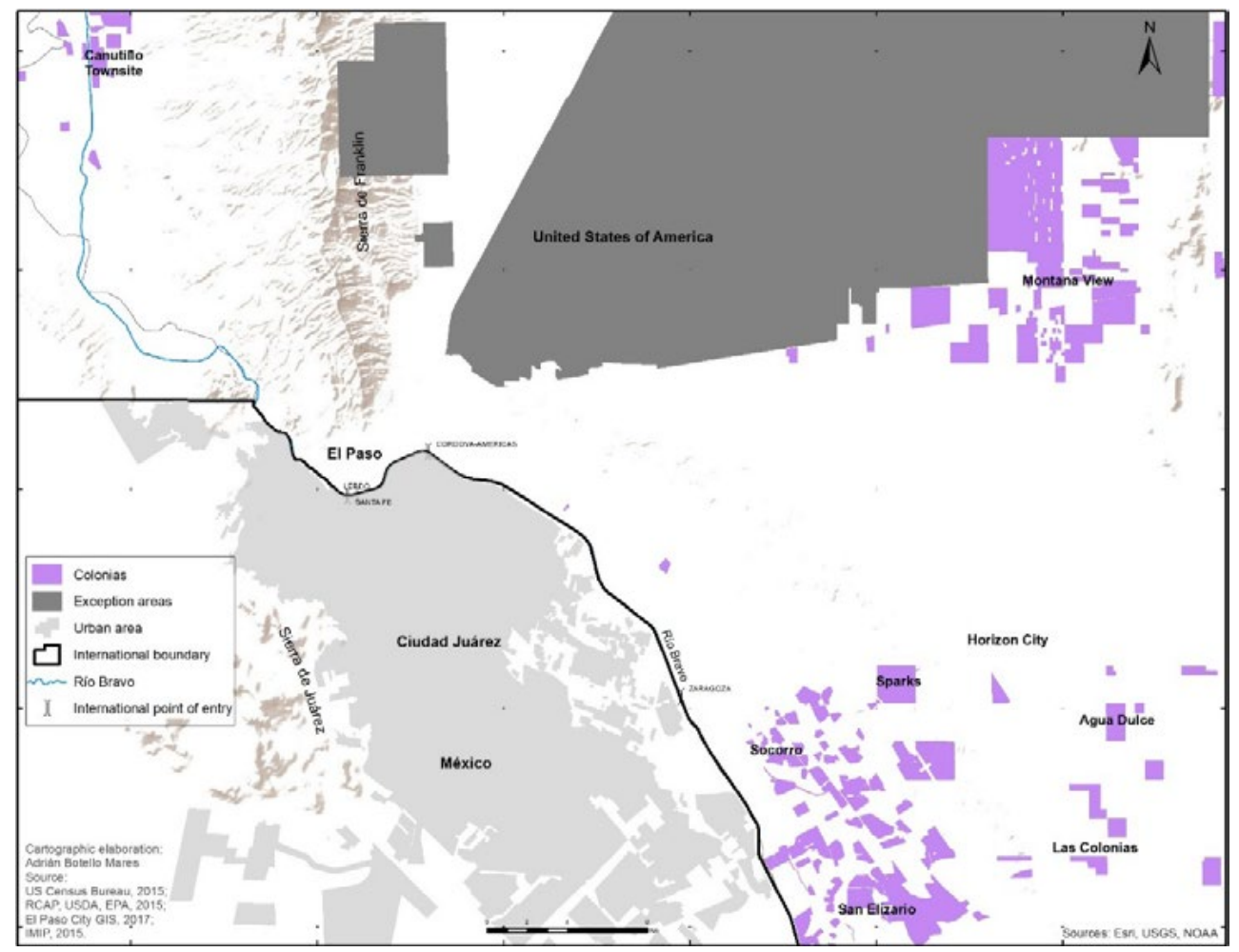

Source: Original by the authors, based on data from IMIP, 2015; USGS, 2015; RCAP, USDA, 2015.

The largest number of settlements and population in the Colonias of El Paso are located in the extreme southeast of the urban area, adjacent to the towns of Horizon City, Socorro and San Elizario. In the map, Sparks and Agua Dulce colonias are highlighted in southwest and east of Horizon City respectively, as well as Las Colonias del Paso, ${ }^{3}$ in north of San Elizario and south of Agua Dulce. In the far northeast, there is a large territorial extension of colonias, although they still have

3 The name of this colonia is an example of the influence, closeness and cultural affinity with Mexico. This colonia is called with the term in Spanish of "Las Colonias", following the geographic reference located in the county of El Paso, with a contraction of the words "De El Paso" in "Del Paso", without following the rules of the spanish language, rather following the symbolic criteria of the use of the most common language in the settlement.

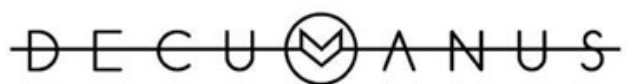

REVISTA INTERDISCIPLINARIA SOBRE ESTUDIOS URBANOS
Núm. 5. Vol. 5. Octubre 2019-Octubre 2020. Instituto de Arquitectura, Diseño y Arte.

Universidad Autónoma de Ciudad Juárez. ISSN: 2448-900X 
low population, except for Montana View subdivision. In the northwest, there are also some colonias, being Canutillo townsite an example of a traditional settlement in the area.

\section{Methods and data analysis}

For the assessment of residential segregation, to be make by means of a multicriteria analysis, we consider the dissimilarity criterion proposed by Sabatini (2004), which is based on the measurement of the spatial relationship of contiguity, and examines the socio-spatial homogeneity or agglomeration within units of spatial aggregation. This criterion considers that the appropriate segregation indicators are those that show better the social composition of the area. In addition, it measures the agglomeration of a same social condition, prioritizing contiguity over proximity. Based on this perspective, we use the geo-demographic classification approach, proposed by Aguilar and Mateos (2011), to identify residential areas from the elements that define residential conditions, such as basic housing services, accessibility and the characteristics of the population.

For the integration of a Residential Segregation Model of El Paso (RSMEP), we used a multicriteria analysis approach, defined by Barredo (1996) as set of spatial operations to achieve an objective, taking into consideration all the intervening variables simultaneously, implemented in a Geographic Information Systems (GIS) environment. For this process, three groups of variables were defined, to which a weighted value was assigned through an analysis hierarchical process. The variables, the weighting process and the measurement criteria are explained in the following section.

\section{Variables of residential segregation}

In the selection of the factors to build the RSMEP, we distinguished three groups of variables to evaluate: 1. Basic services, 2. Accessibility, and 3. Population characteristics. The basic services and demographic variables were obtained directly from the US Census Bureau (2015) and standardized with a precision according to the level of measurement. Data were georeferenced using the census track as spatial aggregation unit, and converted into in raster datasets of $30 \mathrm{~m}$ spatial resolution

For the parametrization of variables in the group of basic services, we considered the percentage of dwellings in a census block with no sewer system (VSDREN); and with natural gas as its main source of house power (VGAS). Both variables have the least spatial variation, but the highest manifestation of segregation. In the group of accessibility, we considered four variables: the concentration of educational, recreational and cultural equipment spaces (CEQUIP) calculated with a kernel function into a density map; and the distance from a midpoint of the historic downtown and Central Business District (CBD) of the city up to the county limits (CDIST), the distance to the main roads that connect the urban area and

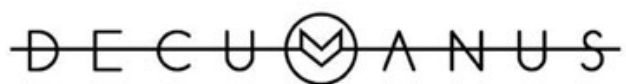

REVISTA INTERDISCIPLINARIA SOBRE ESTUDIOS URBANOS 
the county limits (CVIAL), and distance to public transportation routes (CRUT), all calculated as Euclidean distance models.

In the group of demographic variables, referred to the characteristics that influence the conformation of homogeneous or diverse social groups in the urban space, we considered the annual family income in US dollars (PING), the unemployed population (PDES), the population with access to the social assistance program of the US government Medicaid (PMED), the population without formal education (SINED), the proportion of the Hispanic population by census blocks with emphasis on the blocks with a proportion higher than $98 \%$ of the total (PHISP), as well as the percentage of the population born outside of the country with the status of naturalized citizen or legal resident in the US (PEXT).

Based on the multicriteria analysis approach, for the preparation of the selected parameters to integrate the RSMEP, variables were reclassified in five classes, going from very low to very high susceptibility to residential segregation (RS), according to the following criteria.

Table 1. Variables, parameters and criteria for the integration of the RSMEP

\begin{tabular}{|c|c|c|c|}
\hline Group & Variable & Parameter & Criteria \\
\hline \multirow{2}{*}{ Basic services } & Sewer system & $\begin{array}{l}\text { \% VSDREN by cen- } \\
\text { sus block }\end{array}$ & $>$ Percentage $>$ RS \\
\hline & Natural gas & $\begin{array}{c}\% \text { VGAS by census } \\
\text { block }\end{array}$ & $>$ Percentage $<$ RS \\
\hline \multirow{4}{*}{ Accessibility } & Distance from CBD & CDIST in kilometers & $>$ Distance $>$ RS \\
\hline & Urban equipment & CEQUIP & $>$ Service<RS \\
\hline & Public transportation & CRUT in kilometers & > Distance>RS \\
\hline & Main roads & CVIAL in kilometers & $>$ Distance $>$ RS \\
\hline \multirow{6}{*}{$\begin{array}{l}\text { Population character- } \\
\text { istics }\end{array}$} & Family income & PING in US dollars & $<$ Income $>$ RS \\
\hline & $\begin{array}{l}\text { Unemployed popu- } \\
\text { lation }\end{array}$ & $\begin{array}{l}\text { PDES by census } \\
\text { block }\end{array}$ & $>$ Population $>$ RS \\
\hline & $\begin{array}{l}\text { Population with } \\
\text { Medicaid service }\end{array}$ & $\begin{array}{l}\text { PMED by census } \\
\text { block }\end{array}$ & $>$ Population $>$ RS \\
\hline & $\begin{array}{l}\text { Population without } \\
\text { education }\end{array}$ & $\begin{array}{l}\text { SINED by census } \\
\text { block }\end{array}$ & $>$ Population $>$ RS \\
\hline & Hispanic population & $\begin{array}{l}\text { \% PHISP by census } \\
\text { block }\end{array}$ & $>$ Percentage $>\mathrm{RS}$ \\
\hline & $\begin{array}{l}\text { Foreign population } \\
\text { with citizenship }\end{array}$ & $\begin{array}{l}\text { \%PEXT by census } \\
\text { block }\end{array}$ & $>$ Percentage $>\mathrm{RS}$ \\
\hline
\end{tabular}

Source: Original by the authors, 2020.

For the VSDREN variable reclassification criteria, the higher the percentage of dwellings without sewer service in a census block, the higher the residential segregation, because the susceptibility to segregation derives from the lack of

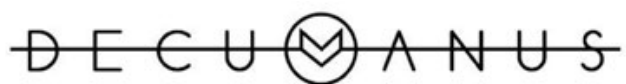

REVISTA INTERDISCIPLINARIA SOBRE ESTUDIOS URBANOS 
access to this service. Conversely, in the VGAS variable the criterion considered that the higher the percentage of gas consumption, the lower the susceptibility to residential segregation. In the accessibility group, we considered the distances to the $\mathrm{CBD}$, main roads and public transportation routes, because the inaccessibility to those points for employment, health, education of consumption activities might increase the susceptibility to segregation. In the case of the CEQUIP variable, the criterion indicates that the higher the number of equipped spaces, the lower the susceptibility to residential segregation due the opportunities that spaces provide social and cultural interaction. Regarding the unemployed population (PDES), population with Medicaid service (PMED), population without education (SINED), percentage of Hispanics (PHISP), and percentage of people born outside the country (PEXT), the criteria are similar: the higher the population, the higher the susceptibility to segregation. In the case of the PING variable, when receiving less money, the population tend to be more susceptible to segregation.

This definition of parameters was made from a natural statistical distribution of the data (natural jenks breaks), but we assigned round numbers manually in the classification of each of the five classes, according to the previously processed data. When calculated, we applied the reclassification criteria according the following intervals for each variable:

Table 2. Parameters reclassification intervals

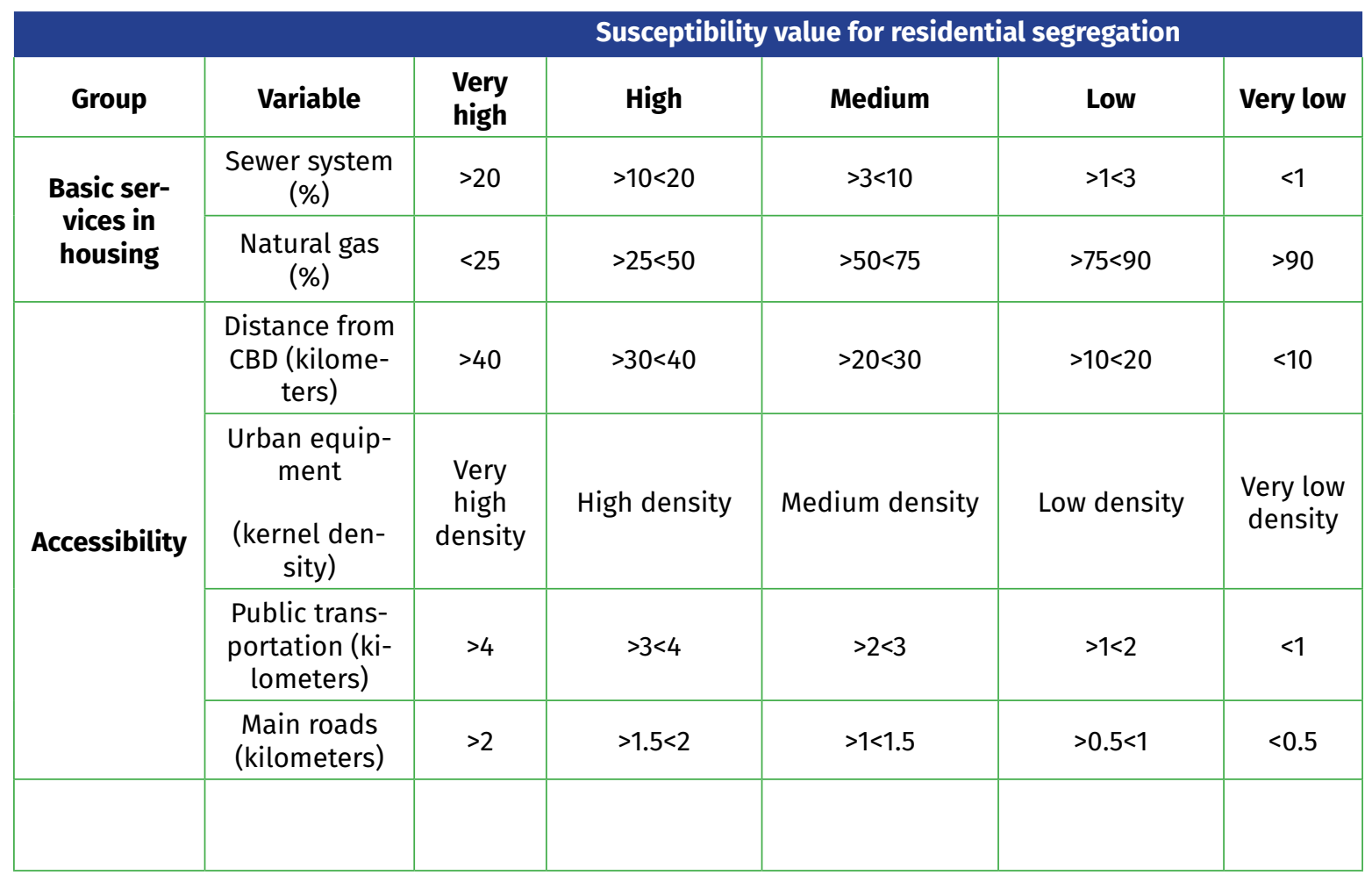

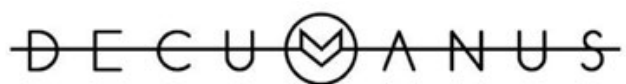

REVISTA INTERDISCIPLINARIA SOBRE ESTUDIOS URBANOS
Núm. 5. Vol. 5. Octubre 2019-Octubre 2020. Instituto de Arquitectura, Diseño y Arte.

Universidad Autónoma de Ciudad Juárez. ISSN: 2448-900X 


\begin{tabular}{|c|c|c|c|c|c|c|}
\hline \multicolumn{7}{|c|}{ Susceptibility value for residential segregation } \\
\hline \multirow{6}{*}{$\begin{array}{c}\text { Population } \\
\text { characteris- } \\
\text { tics }\end{array}$} & $\begin{array}{l}\text { Family income } \\
\text { (dollars) }\end{array}$ & $<25,000$ & $>25,000<30000$ & $>30,000<50000$ & $>50,000<90,000$ & $>90,000$ \\
\hline & $\begin{array}{c}\text { Unemployed } \\
\text { population } \\
\text { (total popula- } \\
\text { tion) }\end{array}$ & $>1,500$ & $>1,000<1,500$ & $>500<1,000$ & $>250<500$ & $<250$ \\
\hline & $\begin{array}{l}\text { Population } \\
\text { with Medicaid } \\
\text { service (total } \\
\text { population) }\end{array}$ & $>1000$ & $>500<1000$ & $>250<500$ & $>100<250$ & $<100$ \\
\hline & $\begin{array}{l}\text { Population } \\
\text { without edu- } \\
\text { cation (\%) }\end{array}$ & $>100$ & $>70<100$ & $>40<70$ & $>20<40$ & $<20$ \\
\hline & $\begin{array}{c}\text { Hispanic pop- } \\
\text { ulation (\%) }\end{array}$ & $>98$ & $>90<98$ & $>50<90$ & $>25<50$ & $<25$ \\
\hline & $\begin{array}{c}\text { Foreign pop- } \\
\text { ulation with } \\
\text { citizenship (\%) }\end{array}$ & $>40$ & $>30<40$ & $>20<30$ & $>10<20$ & $<10$ \\
\hline
\end{tabular}

Source: Original by the authors, 2020.

Once the parameters were reclassified according the proposed criteria, we created a comparison matrix to confront the importance of each parameter when comparing it with each other. This allowed to assign specific weights for the final model, according to their hierarchy level. For the hierarchy definition of each of the parameters we used the Analytic Hierarchy Process (AHP) from the perspective of Thomas Saaty (2008). This approach is designed to solve complex problems of multiple criteria, whose procedure “...requires the decision maker to provide subjective evaluations of the relative importance of each of the criteria and then to specify his or her preference for each of the decision alternatives and for each criterion. The result of the AHP is a hierarchy with priorities that show the global preference for each of the decision alternatives." (Toskano, 2018).

The matrix resulted in values proportional to the sum of weights for each of the 12 variables, being VSDREN the one with the highest weight, with 0.167 , and CVIAL the one with the lowest weight, with 0.005 , being 1 , the sum of the hierarchical weights (Table 3).

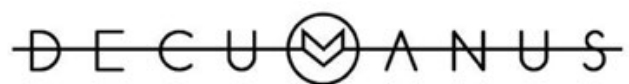

REVISTA INTERDISCIPLINARIA SOBRE ESTUDIOS URBANOS 
Table 3. Comparison matrix

\begin{tabular}{|c|c|c|c|c|c|c|c|c|c|c|c|c|c|c|}
\hline & $\begin{array}{l}\text { Sewer } \\
\text { system }\end{array}$ & $\begin{array}{c}\text { Natural } \\
\text { gas }\end{array}$ & $\begin{array}{l}\text { Distance } \\
\text { from } \\
\text { CBD }\end{array}$ & $\begin{array}{c}\text { Urban } \\
\text { equipment }\end{array}$ & $\begin{array}{c}\text { Public trans- } \\
\text { portation }\end{array}$ & Main roads & $\begin{array}{c}\text { Family } \\
\text { income }\end{array}$ & $\begin{array}{l}\text { Popula- } \\
\text { tion with } \\
\text { Medicaid }\end{array}$ & $\begin{array}{l}\text { Unemployed } \\
\text { population }\end{array}$ & $\begin{array}{c}\text { Population } \\
\text { without edu- } \\
\text { cation }\end{array}$ & $\begin{array}{l}\text { Hispanic } \\
\text { population }\end{array}$ & $\begin{array}{l}\text { Foreign pop- } \\
\text { ulation with } \\
\text { citizenship }\end{array}$ & $\begin{array}{c}\text { Sewer } \\
\text { system }\end{array}$ & $\begin{array}{c}\text { Natural } \\
\text { gas }\end{array}$ \\
\hline $\begin{array}{l}\text { Sewer } \\
\text { system }\end{array}$ & & $\begin{array}{c}\text { Sewer } \\
\text { system }\end{array}$ & $\begin{array}{l}\text { Sewer } \\
\text { system }\end{array}$ & $\begin{array}{l}\text { Sewer } \\
\text { system }\end{array}$ & Sewer system & Sewer system & $\begin{array}{c}\text { Sewer } \\
\text { system }\end{array}$ & $\begin{array}{l}\text { Sewer } \\
\text { system }\end{array}$ & Sewer system & Sewer system & Sewer system & Sewer system & 11 & 0.167 \\
\hline Natural gas & & & $\begin{array}{l}\text { Distance } \\
\text { from } \\
\text { CBD }\end{array}$ & $\begin{array}{c}\text { Urban } \\
\text { equipment }\end{array}$ & $\begin{array}{l}\text { Public trans- } \\
\text { portation }\end{array}$ & Natural gas & $\begin{array}{l}\text { Family } \\
\text { income }\end{array}$ & $\begin{array}{l}\text { Popula- } \\
\text { tion with } \\
\text { Medicaid }\end{array}$ & $\begin{array}{l}\text { Unemployed } \\
\text { population }\end{array}$ & $\begin{array}{c}\text { Population } \\
\text { without edu- } \\
\text { cation }\end{array}$ & $\begin{array}{l}\text { Hispanic } \\
\text { population }\end{array}$ & Natural gas & 2 & 0.030 \\
\hline $\begin{array}{l}\text { Distance } \\
\text { from CBD }\end{array}$ & & & & & $\begin{array}{c}\text { Public trans- } \\
\text { portation }\end{array}$ & $\begin{array}{c}\text { Distance from } \\
\text { CBD }\end{array}$ & $\begin{array}{l}\text { Family } \\
\text { income }\end{array}$ & $\begin{array}{l}\text { Popula- } \\
\text { tion with } \\
\text { Medicaid }\end{array}$ & $\begin{array}{c}\text { Distance from } \\
\text { CBD }\end{array}$ & $\begin{array}{l}\text { Distance from } \\
\text { CBD }\end{array}$ & $\begin{array}{c}\text { Distance from } \\
\text { CBD }\end{array}$ & $\begin{array}{c}\text { Distance from } \\
\text { CBD }\end{array}$ & 6 & 0.091 \\
\hline $\begin{array}{c}\text { Urban } \\
\text { equipment }\end{array}$ & & & & & $\begin{array}{c}\text { Urban equip- } \\
\text { ment }\end{array}$ & $\begin{array}{c}\text { Urban equip- } \\
\text { ment) }\end{array}$ & $\begin{array}{l}\text { Family } \\
\text { income }\end{array}$ & $\begin{array}{l}\text { Popula- } \\
\text { tion with } \\
\text { Medicaid }\end{array}$ & $\begin{array}{c}\text { Urban equip- } \\
\text { ment }\end{array}$ & $\begin{array}{c}\text { Urban equip- } \\
\text { ment }\end{array}$ & $\begin{array}{c}\text { Urban equip- } \\
\text { ment }\end{array}$ & $\begin{array}{l}\text { Urban equip- } \\
\text { ment }\end{array}$ & 8 & 0.121 \\
\hline $\begin{array}{c}\text { Public } \\
\text { transporta- } \\
\text { tion }\end{array}$ & & & & & & $\begin{array}{l}\text { Public trans- } \\
\text { portation }\end{array}$ & $\begin{array}{l}\text { Family } \\
\text { income }\end{array}$ & $\begin{array}{l}\text { Popula- } \\
\text { tion with } \\
\text { Medicaid }\end{array}$ & $\begin{array}{l}\text { Public trans- } \\
\text { portation }\end{array}$ & $\begin{array}{c}\text { Public trans- } \\
\text { portation }\end{array}$ & $\begin{array}{l}\text { Public trans- } \\
\text { portation }\end{array}$ & $\begin{array}{l}\text { Public trans- } \\
\text { portation }\end{array}$ & 7 & 0.106 \\
\hline Main roads & & & & & & & $\begin{array}{l}\text { Ingreso } \\
\text { familiar }\end{array}$ & $\begin{array}{l}\text { Pob. Con } \\
\text { acceso a } \\
\text { Medicaid }\end{array}$ & $\begin{array}{l}\text { Unemployed } \\
\text { population }\end{array}$ & $\begin{array}{c}\text { Population } \\
\text { without edu- } \\
\text { cation }\end{array}$ & $\begin{array}{l}\text { Hispanic } \\
\text { population }\end{array}$ & $\begin{array}{lr}\text { Foreign pop- } \\
\text { ulation } & \text { with } \\
\text { citizenship } & \end{array}$ & 0 & 0.005 \\
\hline $\begin{array}{l}\text { Family } \\
\text { income }\end{array}$ & & & & & & & & $\begin{array}{l}\text { Family } \\
\text { income }\end{array}$ & Family income & Family income & Family income & Family income & 10 & 0.152 \\
\hline $\begin{array}{l}\text { Population } \\
\text { with Med- } \\
\text { icaid }\end{array}$ & & & & & & & & & $\begin{array}{c}\text { Population } \\
\text { with Medicaid }\end{array}$ & $\begin{array}{c}\text { Population } \\
\text { with Medicaid }\end{array}$ & $\begin{array}{c}\text { Population } \\
\text { with Medicaid }\end{array}$ & $\begin{array}{c}\text { Population } \\
\text { with Medicaid }\end{array}$ & 9 & 0.136 \\
\hline $\begin{array}{l}\text { Unem- } \\
\text { ployed } \\
\text { population }\end{array}$ & & & & & & & & & & $\begin{array}{c}\text { Population } \\
\text { without edu- } \\
\text { cation }\end{array}$ & $\begin{array}{l}\text { Hispanic pop- } \\
\text { ulation }\end{array}$ & $\begin{array}{l}\text { Unemployed } \\
\text { population }\end{array}$ & 4 & 0.061 \\
\hline $\begin{array}{l}\text { Population } \\
\text { without } \\
\text { education }\end{array}$ & & & & & & & & & & & $\begin{array}{l}\text { Population } \\
\text { without edu- } \\
\text { cation }\end{array}$ & $\begin{array}{l}\text { Population } \\
\text { without edu- } \\
\text { cation }\end{array}$ & 5 & 0.076 \\
\hline \multirow{3}{*}{$\begin{array}{l}\text { Hispanic } \\
\text { population } \\
\text { Foreign } \\
\text { population } \\
\text { with citizen- } \\
\text { ship } \\
\end{array}$} & & & & & & & & & & & & $\begin{array}{l}\text { Hispanic } \\
\text { population }\end{array}$ & 3 & 0.045 \\
\hline & & & & & & & & & & & & & 1 & 0.010 \\
\hline & & & & & & & & & & & & & 66 & 1.000 \\
\hline
\end{tabular}

Source: Original by the authors, 2020.

In the weighting variables exercise, the sewer system variable was defined as the one with the greatest weight, because it is the one which appears to be the most discriminatory, that is, where the spatial dissimilarity is most evident. Subsequently, the characteristics of the population with respect to the average income and access to Medicaid are listed as the most relevant, both related to the economic characteristics of the colonias residents, which also implies a fundamental feature in the sense of purchasing power, the property of the of urban land and its geographical location. Then, three accessibility variables: urban equipment, public transportation and distance from the CBD, were assigned the next greater weight, highlighting the importance of proximity or access to the areas with the most amenities, and emphasizing the value of the colonias geographical location. The next variables with higher weight are the demographic characteristics, such as the population without formal education, the unemployed population, the Hispanic people and the population born outside of the country. These show an important level of segregation, but without the discrimination power observed in previous variables. Nonetheless, these variables show a strong relationship, since that is the intention of variables conjugation around the measurement of residential segregation. In the second-to-last position appears the variable of the use of natural gas, and last, the access to main roads variable, for their relatively high degree of homogeneity, although not less important in the integration of the model.

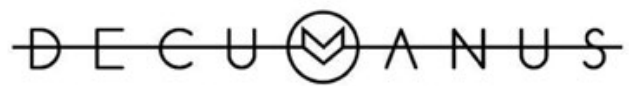

REVISTA INTERDISCIPLINARIA SOBRE ESTUDIOS URBANOS
Núm. 5. Vol. 5. Octubre 2019-Octubre 2020.

Instituto de Arquitectura, Diseño y Arte.

Universidad Autónoma de Ciudad Juárez. ISSN: 2448-900X 


\section{Results}

The individual reclassification of the twelve variables for the integration of the RSMEP shows the susceptibility to residential segregation, presented in Figures 2, 3 and 4, organized by the groups of variables previously defined: basic services, accessibility and population. Based on the weighting criteria for the development of the model, the variables were reclassified, considering the levels of susceptibility, based on Table 2, in such a way that, in this case, the maps represent on a scale ranging from very low to very high susceptibility of residential segregation for each of the variables.

Starting with the situation of sewer system, the reclassified map in Figure 2a shows that the problem of lack of this service is not generalized. However, this situation is what actually defines places more prone to be segregated. In the case of the colonias, the settlements near San Elizario and Horizon City, such as Agua Dulce and Sparks, in southeast of the city, show some lack of this service. Regarding the use of natural gas as the main house power source, showed figure $2 b$, is the lack of this service is evident that in the colonias. In the cases of those near to Horizon City, the segregation susceptibility ranges from medium to high, because its main house power source is Ip gas. In the area of Montana View, in the extreme northeast, the lack of natural gas service is also a recurrent problem.

Figure 2. Susceptibility of residential segregation about basic services variables.

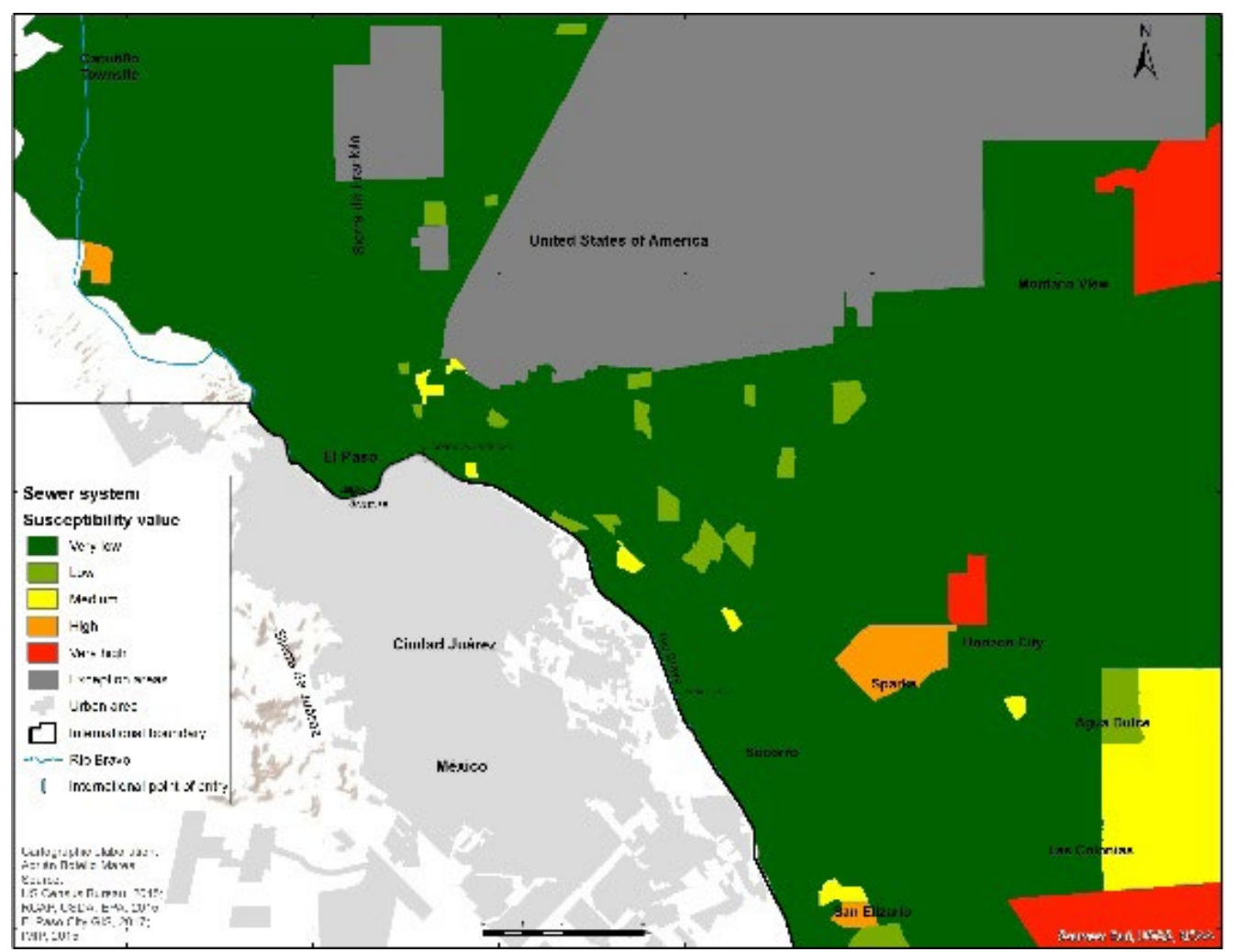

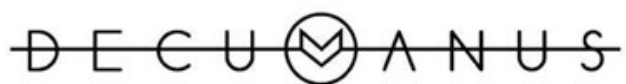

REVISTA INTERDISCIPLINARIA SOBRE ESTUDIOS URBANOS
Núm. 5. Vol. 5. Octubre 2019-Octubre 2020. Instituto de Arquitectura, Diseño y Arte.

Universidad Autónoma de Ciudad Juárez. ISSN: 2448-900X 


\section{a. Percentage of homes without sewer system}

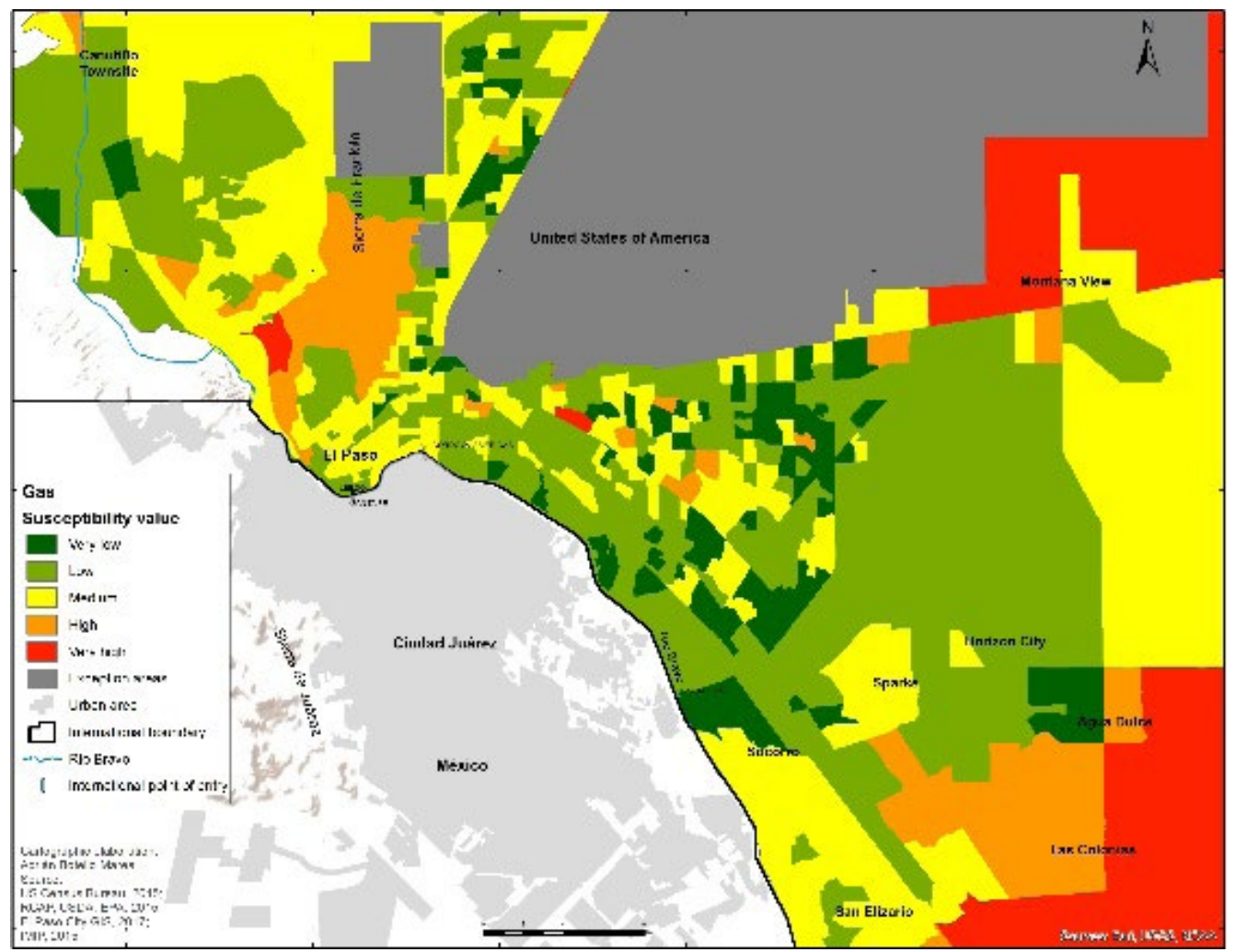

Source: Original by the authors, based on data from IMIP, 2015; USGS, 2015; RCAP, USDA, 2015.

In the group of accessibility variables, as shown in Figure 3a, the most remote colonias are located in the southeast portion of the area, with cases such as Agua Dulce and Las Colonias del Paso being the most remote locations, within the radius of $40 \mathrm{~km}$, in the peri-urban limit of El Paso, Texas, and with a high susceptibility to residential segregation. Sparks, Montana View and Canutillo are located in the radius of $30 \mathrm{~km}$, with a medium level of susceptibility, although Canutillo is closer to the $20 \mathrm{~km}$ range. In the concentration of urban equipment only the central area of the city has a very low susceptibility to segregation. In the consolidated El Paso area, certain polygons of high density and low susceptibility are shown, especially bordering the high concentration CBD zone, to both the north and east portions. The case of the colonias of the southeast and northeast are the most serious in terms of urban equipment lack, with very high susceptibility to segregation, because the insufficient urban equipment, as seen in Figure 3b.

Regarding the susceptibility of segregation by the service of public transportation routes, showed in figure 3c, the area of San Elizario, Agua Dulce and Las Colonias del Paso in the southeast, and Montana View in the northeast, are those with greater affectation, because there is no public transportation routes in those areas. Sparks also shows very high level of susceptibility, although a part of its polygon reaches the high, and not very high, level of lack. The area near Canutillo

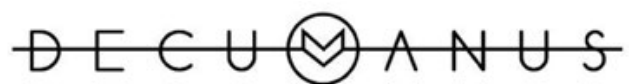

REVISTA INTERDISCIPLINARIA SOBRE ESTUDIOS URBANOS 
has a different reality, because its proximity to some of the Sun Metro urban system routes. The access to main roads does not represent a serious problem in the colonias, the deficiency situation occurs mainly in the outskirts of the urban and suburban area, towards the the county limits, as shown in figure $3 \mathrm{~d}$. The only case with a medium susceptibility occurs in Sparks, because the only main road there is located around the Interstate-10 highway.

Figure 3. Susceptibility of residential segregation about population characteristics variables.

a. Distance from the business center (CBD)

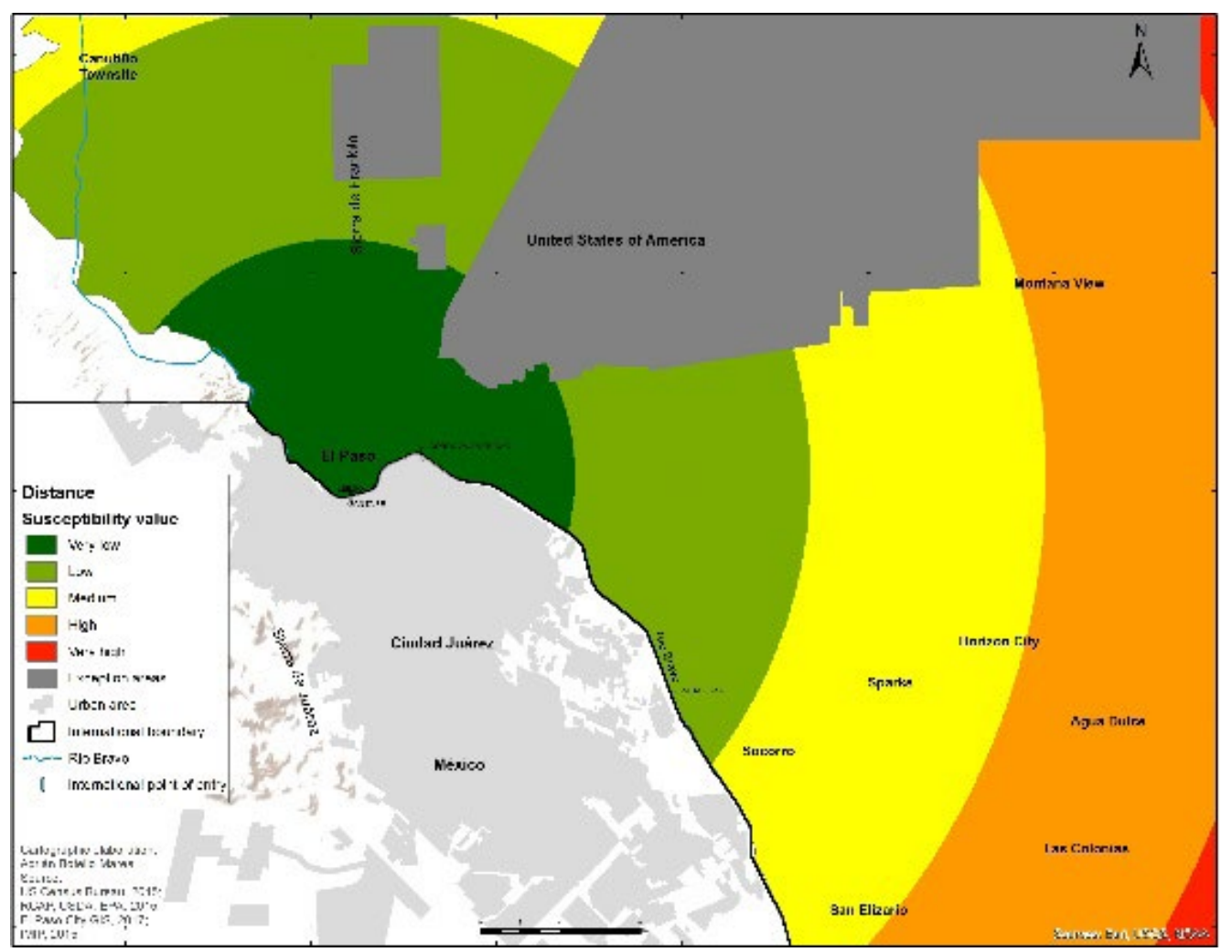

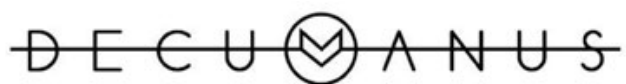

REVISTA INTERDISCIPLINARIA SOBRE ESTUDIOS URBANOS 


\section{b. Concentration of urban equipment}

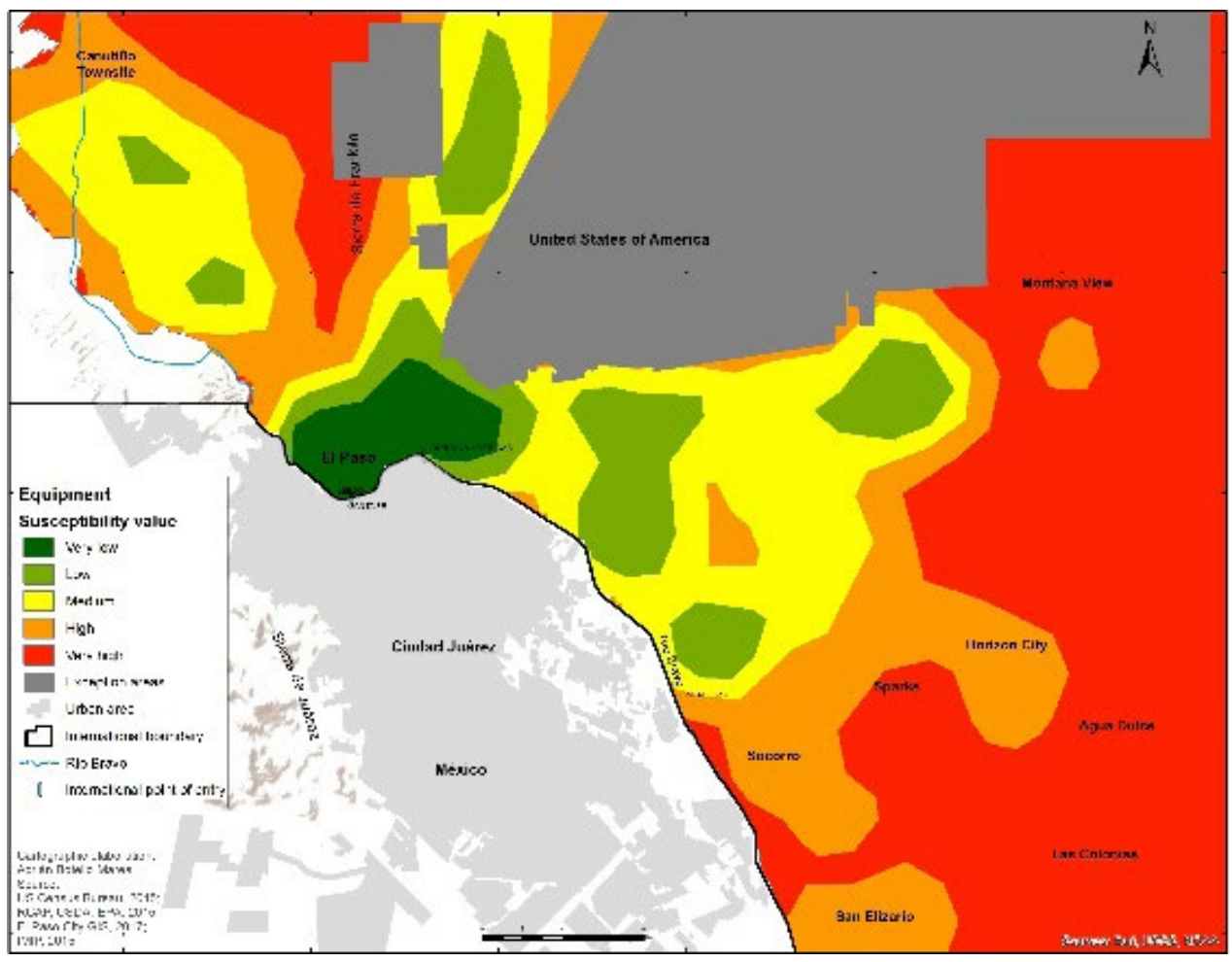

c. Concentration of urban equipment

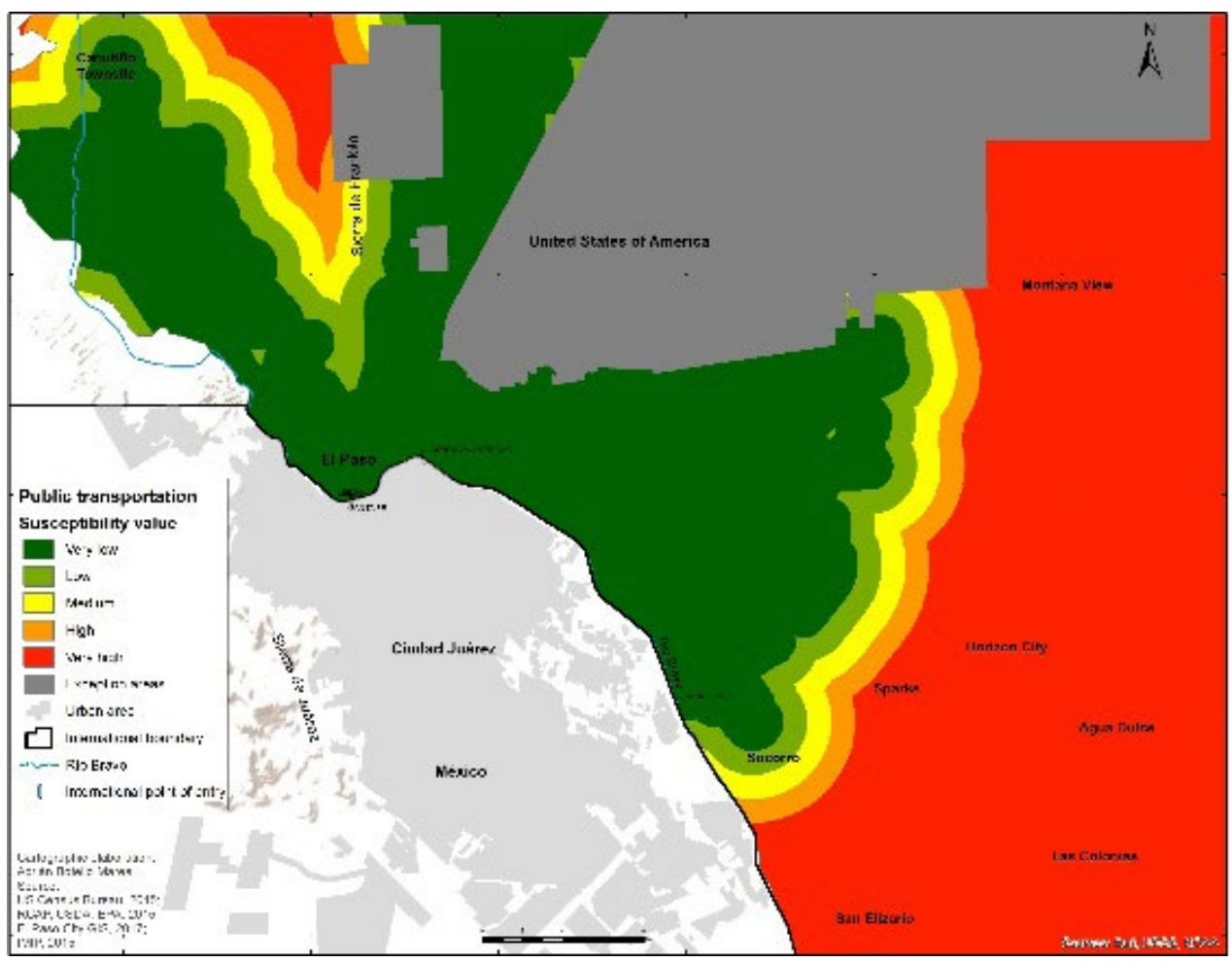

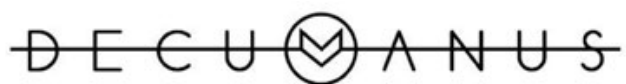

REVISTA INTERDISCIPLINARIA SOBRE ESTUDIOS URBANOS
Núm. 5. Vol. 5. Octubre 2019-Octubre 2020.

Instituto de Arquitectura, Diseño y Arte.

Universidad Autónoma de Ciudad Juárez. ISSN: 2448-900X 


\section{d. Main roads}

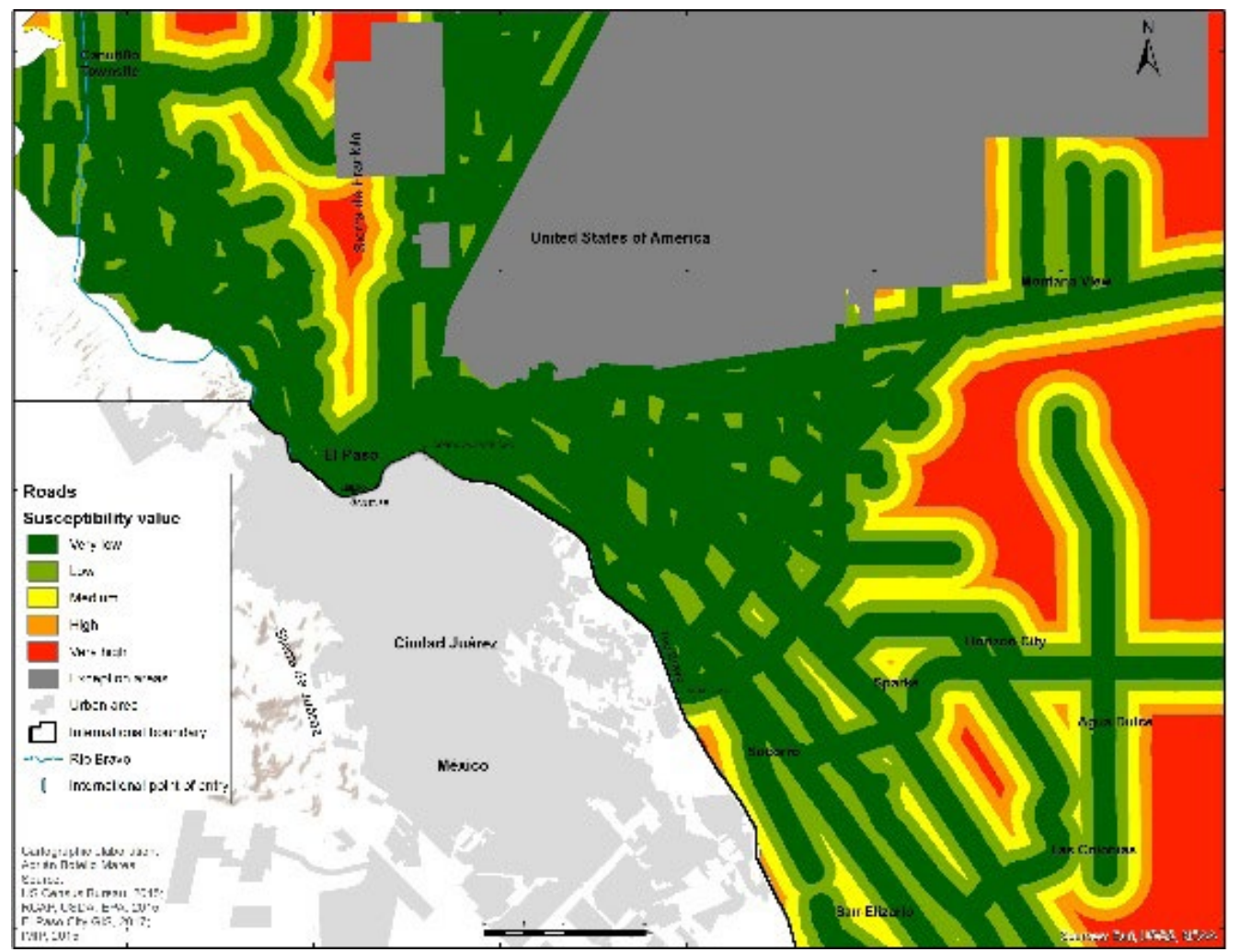

Source: Original by the authors, based on data from IMIP, 2015; USGS, 2015; RCAP, USDA, 2015.

Finally, referring to the variables of population characteristics, in the case of annual household income, the susceptibility to residential segregation is distributed in a large part of the county, highlighting the areas near the Mexican border, as shown in Figure 4a. The colonias near to San Elizario and Horizon City, such as Las Colonias del Paso and Sparks have the lowest income levels, with a very high problem in this area. In Canutillo area, they have low incomes and high susceptibility by this variable, while in Agua Dulce and Montana View, they have a medium income level and susceptibility to residential segregation. The unemployed population has a certain association with the availability of urban equipment spaces, so that the areas with low susceptibility to segregation overlap in several cases. However, this indicator shows a difference between the colonias from southeast and northeast zones with those of the northwest, because it is the only case where the settlements near Canutillo have a medium to high susceptibility, and in the case of Sparks and Agua Dulce colonias the susceptibility to segregation is medium. In addition, is important to note that in Las Colonias del Paso and Montana View the unemployed population variable it is low, as shown in Figure 4b.

The map in Figure 4c shows the level of susceptibility to residential segregation according to the amount of population having Medicaid service. This case is the most illustrative about the existence of a spatial pattern, because the peripheri-

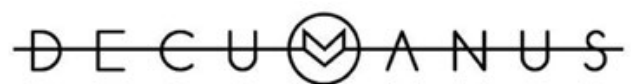

REVISTA INTERDISCIPLINARIA SOBRE ESTUDIOS URBANOS 
cal areas are the most susceptible due the lack of access to this service. The case of Sparks and Agua Dulce have a high level of population with that governmental benefit, while Las Colonias del Paso and Canutillo have a medium to very high level. The susceptibility of regarding access to formal education could be an indicator directly related to the socioeconomic status and the consequent situation of segregation. However, in the case of El Paso, this factor is not of the highest relevance, there is not a clear correlation between population with high income and population without formal studies. This seamsto be the reason because high-income areas that appear in the population map without high education level, as seen in Figure 4d. The case of the colonias is an example of this, because includes census blocks with very low income, but they do not have a problem with population without education, such as in the case of Sparks, Las Colonias del Paso or Canutillo, where the problem is low. The colonias where the level of the population without education is high are the settlements near San Elizario, Agua Dulce and Montana View.

Since the homogeneity in the Hispanic population variable for the whole city is very high, the level of statistical discrimination had to be very rigorous. For this purpose, we did a reclassification with values higher to $90 \%$ of the population for medium to high level, and even higher than $98 \%$ for the case of the very high level. Therefore, the homogeneity is clear, as seen in Figure 4e. The areas with Hispanic population superior to $98 \%$ of the total are located mainly to the far east of the city and county, being the colonias of Sparks, Agua Dulce, Las Colonias del Paso and the San Elizario area the points of highest susceptibility for this variable. The situation regarding to population born outside of the country, has certain relationship with the Hispanic population in El Paso, however, the spatial pattern shows some variations. The concentrations of high and very high susceptibility to segregation are concentrated in the areas adjacent to the border with Ciudad Juárez, as well as in the extreme east and southeast of the metropolitan area and the county (see figure 4f). In the colonias the susceptibility is high and very high because of this variable.

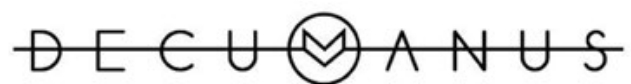

REVISTA INTERDISCIPLINARIA SOBRE ESTUDIOS URBANOS 
Figure 4. Residential segregation susceptibility maps.

a. Average annual household income

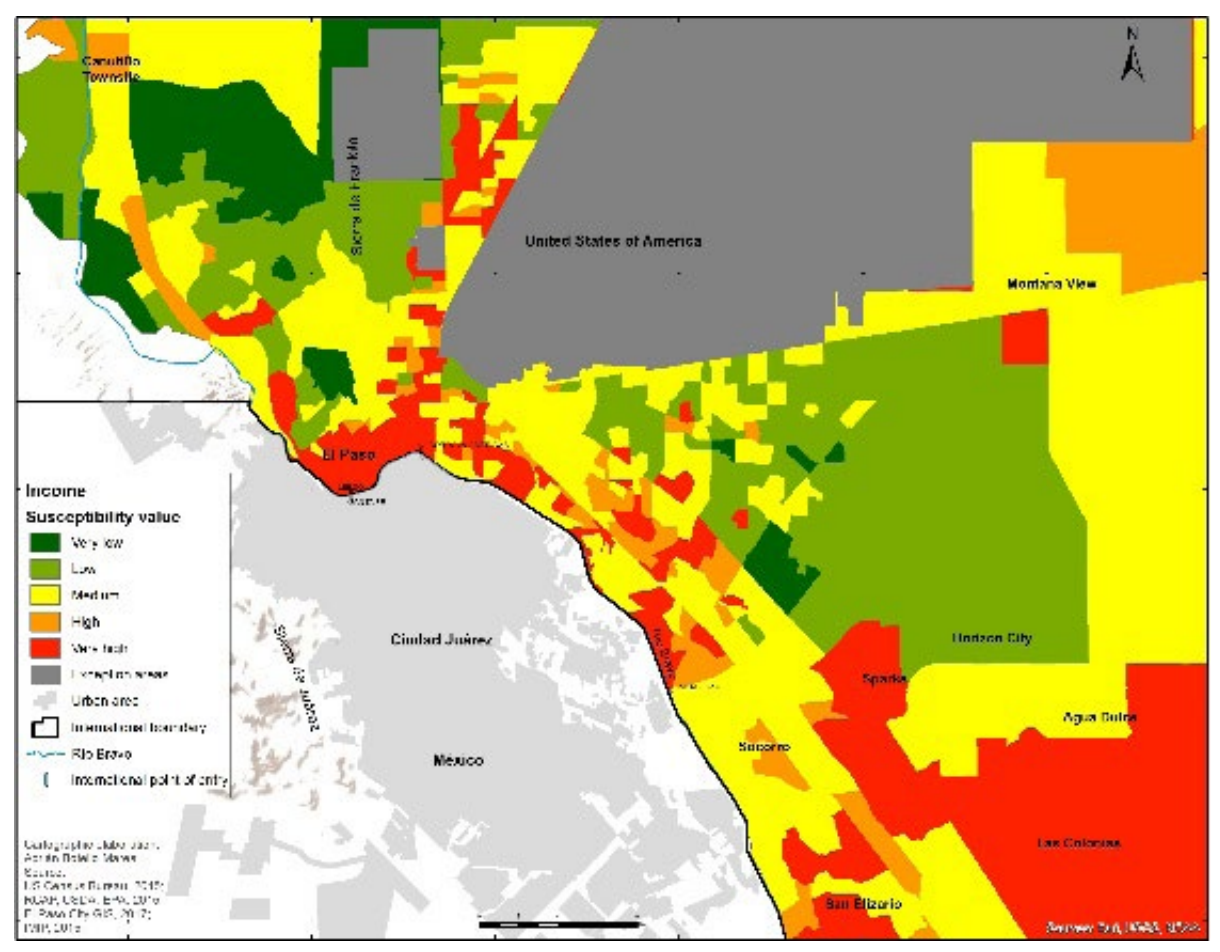

\section{b. Population without employment}

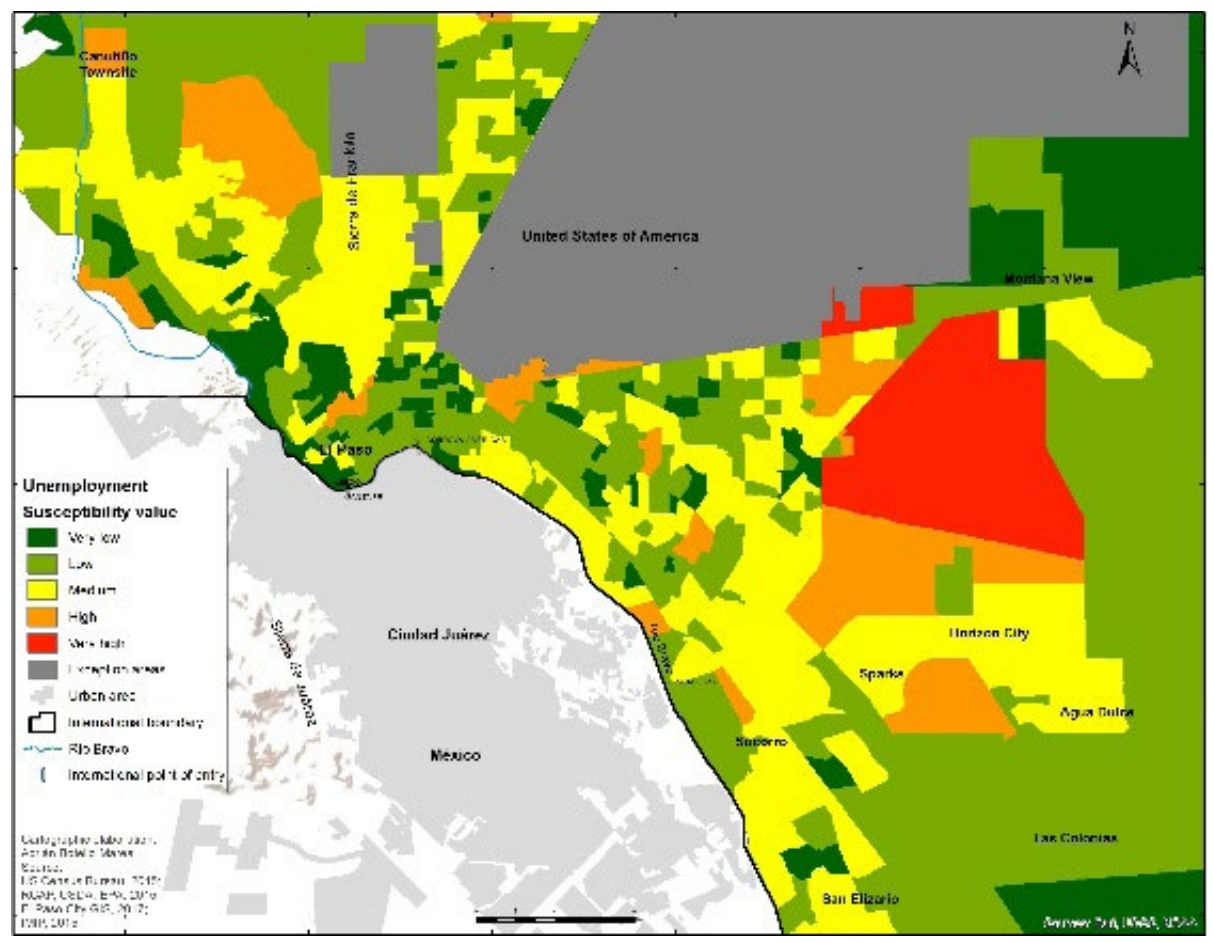

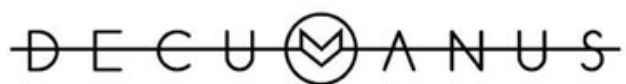

REVISTA INTERDISCIPLINARIA SOBRE ESTUDIOS URBANOS
Núm. 5. Vol. 5. Octubre 2019-Octubre 2020. Instituto de Arquitectura, Diseño y Arte.

Universidad Autónoma de Ciudad Juárez. ISSN: 2448-900X 


\section{b. Population without employment}

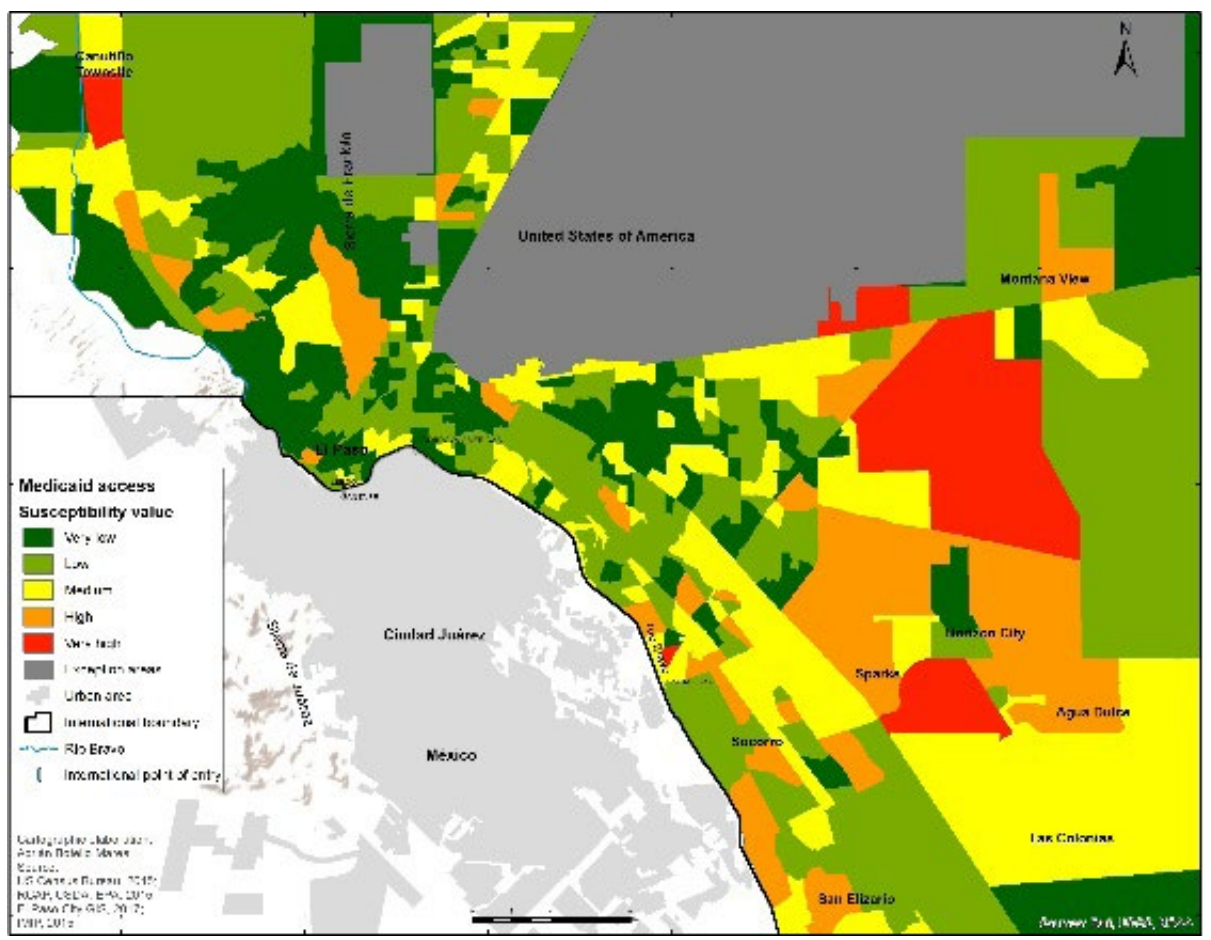

\section{d. Population without formal education}

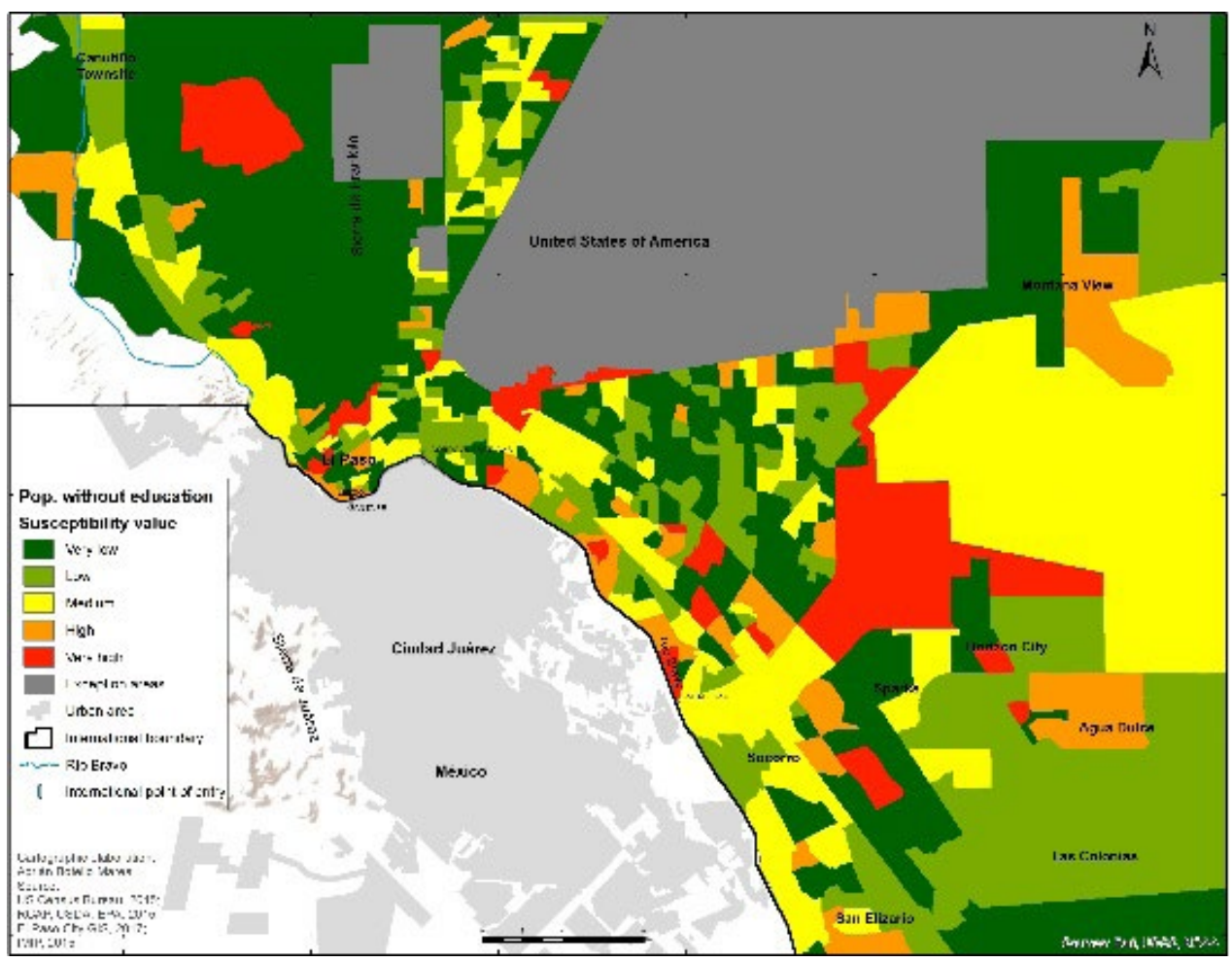

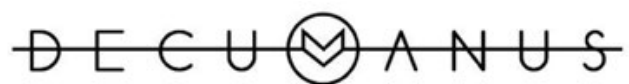

REVISTA INTERDISCIPLINARIA SOBRE ESTUDIOS URBANOS
Núm. 5. Vol. 5. Octubre 2019-Octubre 2020.

Instituto de Arquitectura, Diseño y Arte.

Universidad Autónoma de Ciudad Juárez. ISSN: 2448-900X 


\section{e. Percentage of Hispanic population}

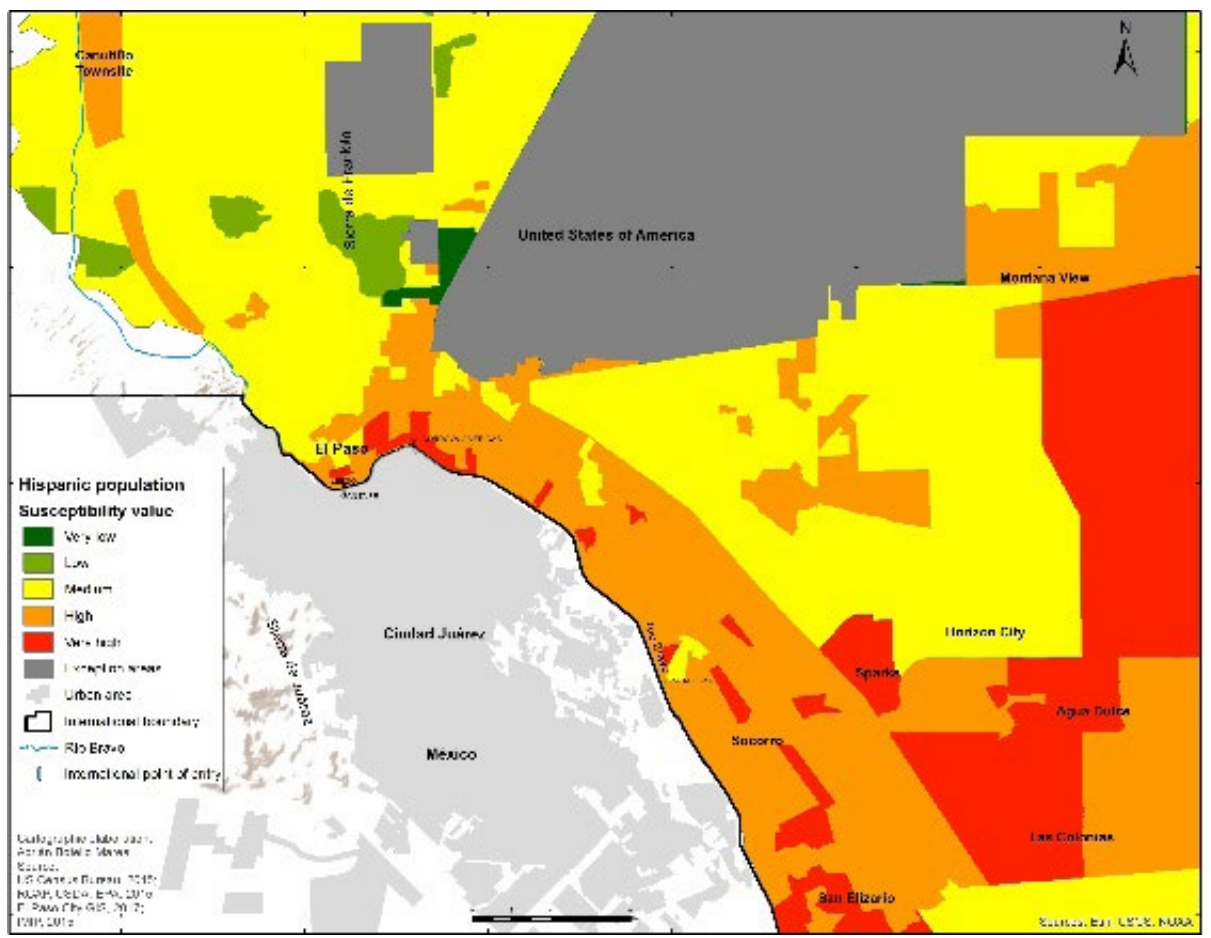

\section{f. Population born in another country}

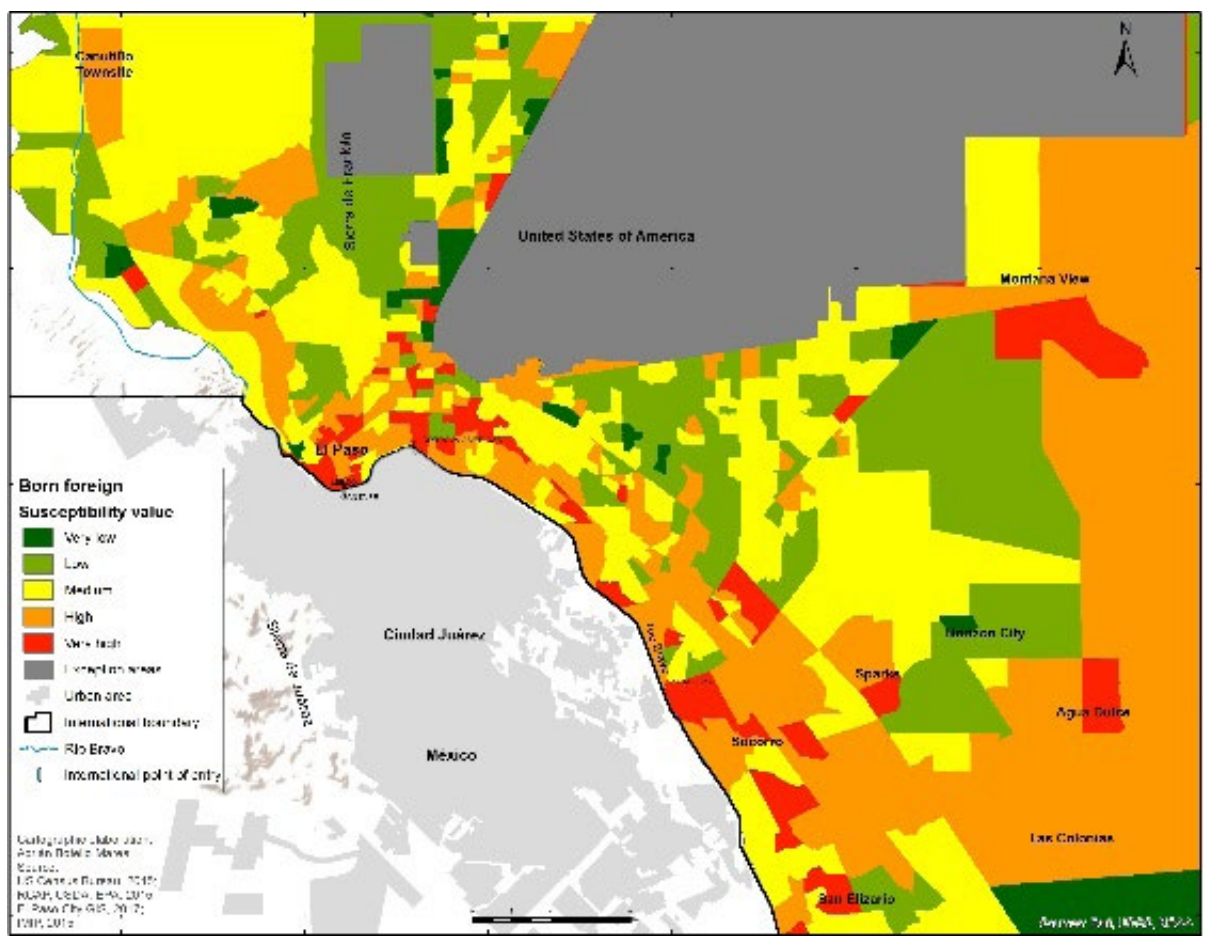

Source: Original by the authors, based on data from IMIP, 2015; USGS, 2015; RCAP, USDA, 2015.

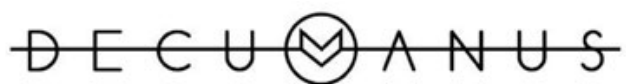

REVISTA INTERDISCIPLINARIA SOBRE ESTUDIOS URBANOS 


\section{Residential Segregation Model of El Paso}

Once the previously estimated weights were assigned to each of the reclassified variables according to their susceptibility value, we integrated the El Paso Residential Segregation Model (RSMEP), using a weighted sum of the 12 variables, according to the following expression:

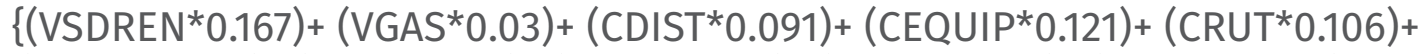

$$
\begin{aligned}
& \left(C V I A L^{*} 0.005\right)+\left(P^{*} G^{*} 0.152\right)+\left(P D E S^{*} 0.061\right)+\left(P^{*}{ }^{*} D^{*} 0.136\right)+(\text { SINED*0.076) }+ \\
& \left.\left(P^{2}{ }^{*} 0.45\right)+\left(\text { PEXT }^{*} 0.01\right)\right\}
\end{aligned}
$$

The RSMEP is the representation of the reclassified variables combined according their specific weights using a raster calculator (Figure 3 ). The summation values range between 1.8 and 6.08 , in a continuous scale, highlighting in colors from orange to red as the areas with higher residential segregation; in yellow the areas with medium levels; and in the shades of green, the areas where there is less residential segregation. It is necessary to clarify the exclusion zone in the military reserves, since these do not adhere to the evaluation criteria, because they are not precisely residential areas.

Figure 5. Residential Segregation Model of El Paso, Texas.

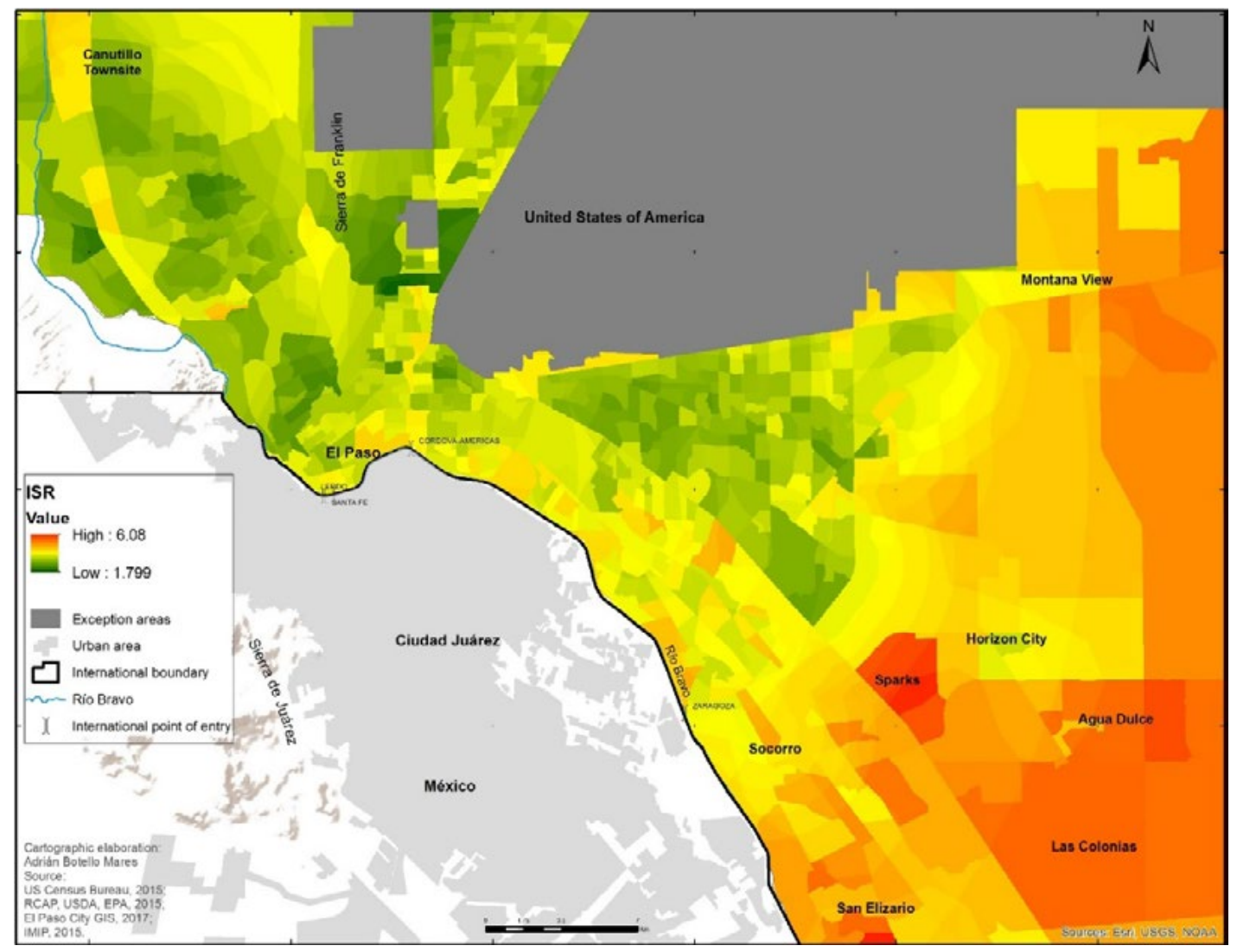

Source: Source: original by the authors, 2020.

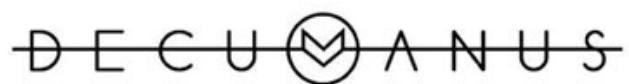

REVISTA INTERDISCIPLINARIA SOBRE ESTUDIOS URBANOS 
The resulting model shows the residential segregation has spatial patterns in clusters for the city of El Paso. There is an important cluster of areas with low residential segregation located in the central part of the city, adjacent to the border crossings points to Ciudad Juarez, and around the most consolidated parts of the city near downtown, such as Franklin Heights, Mills, Campbell, Highland Park, or to the area of Loreto Palace or Zambrano. This pattern is also evident along the Interstate 10 highway, to the north and south, spreading north on Montana Street towards the airport, in the areas with the lowest Hispanic population and with the highest economic income. Likewise, the concentration of low residential segregation extends to the east side, in subdivisions such as Valley View or Cielo Vista Park, up to Vista del Sol, close to the downtown and the broad endowment of main roads, in addition with the proportion of settlements with income above the poverty line. Finally, low segregation levels are present in the west and northwest areas, in the settlements of high and medium high income, such as the subdivisions of Coronado Hills, Cresmont Hills, Mesa Hills, Montecillo and others. Practically one third of the total urban area is at this level of residential segregation (33.8\% of the total), being the second with the highest spatial proportion of all segregation levels.

The lowest segregation levels are found in areas with higher income and relatively less Hispanicized populations, located mainly in the north side of the city, in the neighborhoods adjacent to the airport and Fort Bliss, such as Sunrise Acres or Mountain View. These areas represent only $2.3 \%$ of the total urban area.

Most of the urban area shows a medium level of residential segregation, accounting for $51.7 \%$ of the total model area. The distribution of this areas can be mostly observed towards the city limits of El Paso, but still in some parts of the consolidated urban area. This pattern is also observed to the northwest, from subdivisions such as River Park, Canutillo or West Hills, to places such as Sierra Hills or Franklin Hills. In the southeast, we observed a larger territorial and population proportion characterized by this middle level of residential segregation, with subdivisions such as Vista del Prado, Vista Real or Americas. Towards the north, on the road to Alamogordo, New Mexico, there are also some settlements with this level of segregation, in areas such as North Hills and Dolphin Terrace.

The areas with high and very high segregation do not represent such a large proportion (12.2\% of the total), however, these are required social attention, due to their disadvantageous social condition. In the model, is very clear high segregation levels are concentered in the extreme east, southeast and extreme northeast of the city, corresponding to the area of the colonias, and in the extreme northwest, with less proportion. This pattern corresponds to the premise established from the beginning of this paper. As example of the highest segregation areas we found Horizon City, Socorro and San Elizario in the southeast, specifically in colonias such as Sparks, Agua Dulce or Las Colonias del Paso; as well as in the northeast of the city in areas adjacent to the exit of highway 62 , in the avenue to Montana, in settlements like Montana View Subdivision or Homestad Meadows. In the northwest there are also areas with high levels of residential segregation,

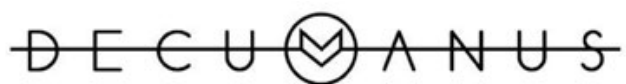

REVISTA INTERDISCIPLINARIA SOBRE ESTUDIOS URBANOS
Núm. 5. Vol. 5. Octubre 2019-Octubre 2020. Instituto de Arquitectura, Diseño y Arte.

Universidad Autónoma de Ciudad Juárez. ISSN: 2448-900X 
specifically in Canutillo Townsite and some nearby settlements, although the levels are not as high as in the east of El Paso. According to the model, the income conditions below the poverty line, the distance from the city central district, the lack of public transportation routes service, as well as the deficiencies in basic services within their homes determine this situation.

\section{Conclusions}

The urban configuration of the city of El Paso, Texas, results from a complex historical process where problems such as residential segregation are not outsiders in a city of a country of the so-called developed world. It is visible then, that these manifestations do not have an exclusive geographical delimitation in the world, despite they exhibit geopolitical patterns of location in undeveloped countries. There is no geographic exclusivity in terms of segregation, so the conditions of the disadvantaged are not necessarily exclusive of any particular region, at least not in absolute terms.

For the particular case of the urban areas of El Paso, Texas and its peri urban colonias, is important to highlight that the highest levels of residential segregation are located mainly on the furthest urban periphery, more specifically in the colonias near to Horizon City, San Elizario and Socorro, showing particular spatial patterns with evident segregation in all areas from negative results in practically all the variables analyzed. The resulting model provides evidence on the need for priority attention to the areas with higher levels of residential segregation, and therefore the need to motivate a deeper understanding of the problem undertaken here. The role of research in this matter, as a creative entity and builder of thought and knowledge associated with the assertive promotion of public policies aimed at solving the negative effects of residential segregation, improves this possibility.

The support of geotechnological tools and spatial analysis methodologies allow us to give a valuable approach for the identification of phenomena such as residential segregation. Nonetheless, remains open the possibility to continue building in terms of knowledge, and ultimately in terms of solutions, without distinction of developed or undeveloped worlds.

\section{References}

Aguilar, A. G. \& Mateos, P. (2011). Diferenciación sociodemográfica del espacio urbano de la Ciudad de México. Chile: Revista EURE.

Barredo, J. I. (1996). Sistemas de Información Geográfica y evaluación multicriterio en la ordenación del territorio. España: Ra-Ma Editorial.

Botello Mares, A. (2019). Construcción socioespacial objetiva y subjetiva de la segregación residencial en Ciudad Juárez. Ciudad Juárez: El Colegio de Chihuahua.

Castells, M. (1978). La cuestión urbana. México: Siglo XXI.

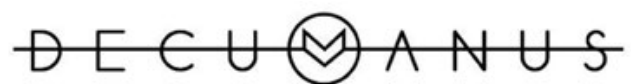

REVISTA INTERDISCIPLINARIA SOBRE ESTUDIOS URBANOS 
City of El Paso (2018). El Paso GIS. El Paso, Texas: Department of Information Technology Services.

City of El Paso (2012). Plan El Paso: A Policy Guide for El Paso for the next 25 years and beyond. El Paso, Texas: Department of planning.

Mauleón, V., \& Ting, C. (Octubre de 2017). El Paso: Texas Colonias. Obtenido de https:// projects.journalism.berkeley.edu/border/elpasocolonias.html

Olmedo, C. (2014). Empowering Change in Texas Colonias: A Proposal to Provide Electricity Access to Colonia Residents. Austin, Texas: The University of Texas at Austin.

Rivera, D. (2014). The Forgotten Americans: A Visual Exploration of Lower Rio Grande Valley Colonias. Michigan Journal of Sustainability, s.p.

Rodríguez, J., \& Arriagada, C. (2004). Segregación residencial en la ciudad latinoamericana. Revista EURE, s.p.

Saaty, T. (2008). Decision making with the Analytic Hierarchy Process. EUA: International Journal of Services Sciences.

Sabatini, F. (2002). La segregación social del espacio en las ciudades de América Latina. Washington D.C.: Banco Interamericano de Desarrollo.

Sabatini, F. (2004). Medición de la segregación residencial: reflexiones metodológicas desde la ciudad latinoamericana. Chile: Instituto de Geografía, PUC Chile.

Sánchez, E. Et al. (2013). Land change and urban growth in binational U.S.-Mexico conurbation. Ciudad Juárez: UACJ.

Texas Secretary of State (Enero de 2020). Colonia Legislation in Texas. Obtenido de https://www.sos.state.tx.us/border/reports/legislation.shtml

Toskano, G. (2018). El Proceso de Análisis Jerárquico como herramienta para la toma de decisiones en la selección de proveedores. Perú: Tesis de la UNMSM.

Ward, P. (1999). Colonias and Public Policy in Texas and Mexico: Urbanization by Stealth. Austin: University of Texas Press.

Ward, P. (2012). Segregación residencial: la importancia de las escalas y de los procesos informales de mercado. Buenos Aires: Revista del área de Estudios Urbanos. UBA.

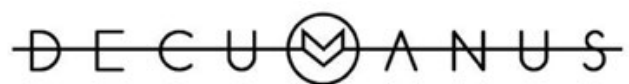

REVISTA INTERDISCIPLINARIA SOBRE ESTUDIOS URBANOS
Núm. 5. Vol. 5. Octubre 2019-Octubre 2020. Instituto de Arquitectura, Diseño y Arte.

Universidad Autónoma de Ciudad Juárez. ISSN: 2448-900X 